\title{
Trace Elements in Children with Chronic Liver Disease
}

\author{
Dhiaa H Al-Baldawi, Rabab Farhan Thajeel*, and Wassan A Najim
}

Department of Pediatric Gastroenterology, College of Medicine, Baghdad University, Iraq

*Corresponding author: Rabab Farhan Thajeel, ABP Pediatric Gastroenterologist, Department of Pediatric Gastroenterology, College of Medicine, Baghdad University, Iraq, Tel: +964 1778 7086; E-mail: farhan_rabab@yahoo.com

Rec date: Aug 07, 2017; Acc date: Aug 21, 2017; Pub date: Aug 23, 2017

Citation: Thajeel RF, Al-Baldawi DH, Najim WA (2017) Trace Elements in Children with Chronic Liver Disease. J Clin Gastroenterol Hepatol Vol.1 No.2:20.

\section{Abstract}

Background: Trace elements have a major role as oxidant and antioxidants, promoting and protecting from tissue damage respectively. As the liver has a pivotal role in trace elements metabolism and consequently their bioavailability. Child-Pugh score is used to assess liver disease severity as the patients classified into group A, B and $\mathrm{C}$ according to five parameters: total serum bilirubin, ascites, encephalopathy, pro-thrombin time and serum albumin.

Objective: We aim to measure serum level of trace elements in patients with chronic liver disease (zinc, copper, iron, total iron binding capacity and ferritin) and highlight its association with gender, age and child Pughscore.

Patient and methods: An analytical cross section study was done in Baghdad Medical City from the first of February 2014 to the thirtieth of September 2014. Two hundred cases, one hundred patients with chronic liver disease and one hundred control group with age ranging from 1 month to 13 years. Data including age and sex for all patients'groups were recorded. Blood samples were taken from all patients and the control group members who were enrolled in study to investigate the serum level of (zinc, copper, iron, total iron binding capacity and ferritin).

All patients were assessed for severity of ascites, the presence of hepatic encephalopathy and sent for total serum bilirubin level, prothrombin time, international normalized ratio (INR) and serum albumin for assessing Child Pugh-score classification to divide patient in 3 classes (A, B and C).

Results: Serum zinc and total iron binding capacity were lower in the patients than in the control group, while serum copper, iron and ferritin were higher in the patients than the control but with no statistical significance. Also, the serum zinc and total iron binding capacity decrease as Child Pugh-score increase in severity, on the other hand serum copper, iron and ferritin increase as the Child Pughscore increases in severity but with no statistical significance. Regarding age and gender, there were no statistical significance between their categories and the study parameters.

Conclusion: These results encourage inclusion of serum zinc, copper, iron, total iron binding capacity and ferritin as biomarkers for monitoring the severity of the liver damage during assessment of children with chronic liver diseases. We also recommend avoiding excess iron and copper intake in those patients, whereas zinc supplementation should be encouraged.

Keywords: Chronic liver disease; Redox processes; Environmental toxins; Radicals

\section{Introduction}

Chronic liver diseases (CLD) are marked by gradual destruction of liver tissue over time. CLD in children are considered as an important health problem. They have a disastrous effect on health, hence economic potential of affected persons. Many risk factors are associated with liver disorders; these are infectious and environmental toxins. Synergism of more than one factor may enhance the process of liver damage [1].

A growing body of evidence indicates that many trace elements play an important role in a number of biological processes through their activation or inhibition of the enzymatic reactions, their competing with other elements and metalloproteins for binding sites, their affecting permeability of cell membranes or other mechanisms.

Trace elements such as iron (Fe), copper ( $\mathrm{Cu}$ ) and zinc $(\mathrm{Zn})$ exert important protective or enhancing effects of some diseases [2]. The liver regulates the metabolic pathway and transport of trace elements, and consequently their bioavailability, tissue distribution and eventually toxicity. The liver also plays a role in the excretion of trace elements through bile formation [3].

Copper functions in a diverse process such as infant growth, bone strength, host defense mechanisms, iron transport [4]. It has important role in redox processes. Reactive copper can participate in liver damage directly or indirectly through Kupfer cell stimulation [5]. Dietary copper is absorbed in the stomach 
and duodenum and is rapidly taken up from the portal venous circulation by the liver, the principle organ involved in copper homeostasis. Biliary excretion is the sole mechanism for copper elimination, so any perturbation of this process can result in hepatic copper accumulation and liver damage [6].

Zinc augments the natural defense of reactive oxygen radicals. Zinc acts as an antioxidant, a membrane and cytoskeletal stabilizer, an anti-apoptotic agent, an important co-factor in deoxyribonucleic acid (DNA) and antiinflammatory agent [5]. Patients with liver disease, often have poor diets that are low in protein and low in zinc. Absorption of $\mathrm{Zn}$ is concentration dependent and occurs throughout the small intestine (mainly jejunum). Absorption may be impaired in cirrhosis, and typically there is increase urinary excretion of Zn in cirrhosis [7].

Iron plays a fundamental role in oxygen-carrying proteins such as hemoglobin and myoglobin. However; iron can be toxic when present in excess [8]. Liver is an important organ in iron homeostasis. Besides its involvement in iron storage, the liver also produces transferrin and hepcidin an iron carrier protein in plasma and a hormone regulating iron metabolism, respectively [9]. When liver damage occurs, there is a decrease in hepcidin production lead to increase iron absorption [10].

\section{Aim of study}

To evaluate serum level of trace elements in patients with chronic liver disease (zinc, copper, iron, total iron binding capacity and ferritin) and to find out the association between gender, age, causes and Child Pugh-score.

\section{Patients and Methods}

Cross sectional study was conducted in Children Welfare Teaching Hospital, Baghdad, Iraq during period from the first of February 2014 to the thirtieth of September 2014. A total number of 100 randomly selected patients with chronic liver disease attending Gastroenterology and Hepatology unit and outpatient clinic with age range from 1-month to 13 years, categorizing them into infants (1-12 months), toddlers (1-3 years), preschool (3-6 years), school age (6-12 years) and more than 12 years considered as teenagers. All patients included in this study were diagnosed with criteria of presence of chronic liver disease for more than 3 months duration or physical stigmata of chronic liver disease (clubbing, spider telangiectasia, hepatosplenomegaly) [11]. Patient that were excluded from this study included those who were on zinc or iron supplements,

Also, cases of Wilson disease were excluded from the study of copper statistics, in addition 100 of healthy children which were sex and age matched used as control cases.

The studied patients, age, sex and causes of chronic liver disease were recorded Patients with chronic liver disease included in the study were, infections with hepatitis B and C, autoimmune liver disease, biliary tree anomalies, metabolic liver diseases mainly galactosemia and tyrosinemia and glycogen storage diseases and cases of undiagnosed chronic liver diseases. All of them underwent the following: evaluating total bilirubin level, serum albumin, prothrombin time with INR (international normalized ratio), the degree of ascites and the grade of hepatic encephalopathy for assessment of ChildPugh score to assess chronic liver disease severity.

The degree of ascites was assessed clinically and by ultrasound study and graded according to grading system for ascites that has been proposed by the International Ascites Club:

Grade 1: Mild ascites detectable only by ultrasound examination.

Grade 2: Moderate ascites manifested by moderate symmetrical distention of abdomen.

Grade 3: Severe, large gross ascites with marked abdominal distention [12].

Hepatic encephalopathy graded as:

Stage 1: Periods of lethargy and reversal of day-night sleeping.

Stage 2: Drowsiness, agitation and wide mood swinging.

Stage 3: Stupor, confused and incoherent speech.

Stage 4: Coma [13].

All patients and control cases enrolled in the study were subjected to the following laboratory investigations: serum copper, zinc, iron, total iron binding capacity and ferritin.

\section{Statistical Analysis}

The data were reviewed, cleaned with double check entry into the computer using Statistical Package for Social Sciences (SPSS) version 20. The Shapiro-Wilk test was used to test continues variables for their normality of distribution. PePearson's Chi-square test was used to assess statistical association between the categorical data. Independent t-test (two tailed), analysis of variance (ANOVA), Mann-Whitney and Kursakal-Wallis non-parametric tests, and a linear regression were used to assess the continuous variables accordingly. A level of $p$-value less than 0.05 was significant.

\section{Results}

Results of this study were presented in the following tables and figures.

In the case group, male percentage was $51 \%$ and female was $49 \%$. as for age groups infants $46 \%$, toddlers $14 \%$, preschool $12 \%$, school $24 \%$ and teenage $4 \%$. Child Pugh-score distribution was $19 \%$ for group A $49 \%$ and $32 \%$ for group B and $\mathrm{C}$ respectively (Table $\mathbf{1})$.

Comparing the age categories of the case group there was no statistical significance regarding (zinc, copper, iron, total iron binding capacity and ferritin (Table 2). 
There was no statistical significance between male and female in the case group regarding (zinc, copper, iron, total iron binding capacity and ferritin (Table 3).

Zinc level and total iron binding capacity were lower in the case group than in the control group, while iron and ferritin were higher in the case group than the control. Serum copper was higher in case group than control but with no statistical significance (Table 4).

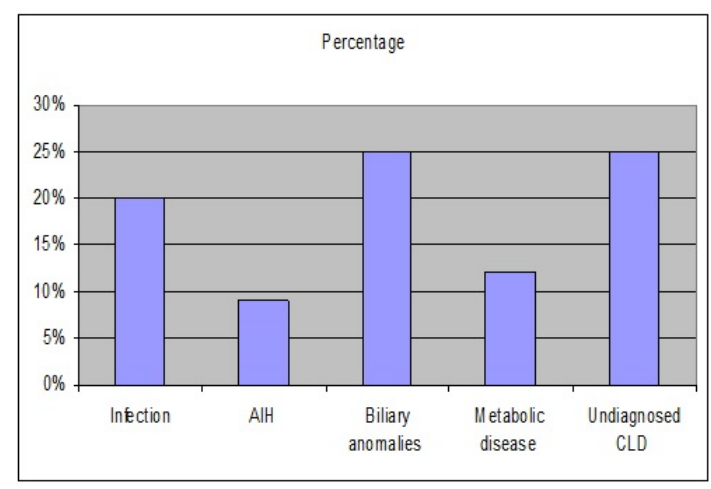

Figure 1 Distribution of the patients according to their causes of liver disease (CLD: Chronic Liver Disease, AlH: Autoimmune Hepatitis, Infections included Hepatitis B and C), While metabolic causes included (galactosemia, tyrosinemia and glycogen storage diseases).
Regarding causes of chronic liver disease, the highest percentage was for biliary anomalies and undiagnosed chronic liver diseases while the lower percentage was for the autoimmune hepatitis (Figure 1).

In Child Pugh-score classification zinc and total iron binding capacity were lower in group $C$ than $A$ and $B$. Copper and iron were higher in group $C$ than $A$ and $B$ but with no statistical significance (Table 5).

Table 1 Distribution of the study participants according to their gender, age categories and Pugh-score $n=100$.

\begin{tabular}{|l|l|l|}
\hline \multicolumn{2}{|l|}{ Variables } & Cases No. (\%) \\
\hline \multirow{2}{*}{ Gender } & Male & $51(51.0 \%)$ \\
\cline { 2 - 3 } & Female & $49(49.0 \%)$ \\
\hline \multirow{2}{*}{ Age of patients } & Infant (1 month-12 months) & $46(46.0 \%)$ \\
\cline { 2 - 3 } & Toddler (1 year-3 years) & $14(14.0 \%)$ \\
\cline { 2 - 3 } & Preschool (3 years-6 years) & $12(12.0 \%)$ \\
\cline { 2 - 3 } & School (6 years-12 years) & $24(24.0 \%)$ \\
\cline { 2 - 3 } & Teenage $>12$ years & $4(4.0 \%)$ \\
\hline \multirow{2}{*}{ Pugh score } & A & $19(19.0 \%)$ \\
\cline { 2 - 3 } & B & $32(32.0 \%)$ \\
\hline & C & $49.0 \%)$ \\
\hline
\end{tabular}

Table 2 Comparison of the levels of serum zinc, total iron binding capacity (TIBC), copper, iron and ferritin according to the age categories of the patients, $n=100$.

\begin{tabular}{|c|c|c|c|c|c|}
\hline Variable & $\begin{array}{l}\text { Zinc } \mu \mathrm{g} / \mathrm{dL} \\
\text { Mean } \pm(\mathrm{SD})\end{array}$ & $\begin{array}{l}\text { TIBC } \mu \mathrm{g} / \mathrm{dl} \\
\text { Median(IQR) }\end{array}$ & $\begin{array}{l}\text { Copper } \mu \mathrm{g} / \mathrm{dl} \\
\text { Mean } \pm(\mathrm{SD})\end{array}$ & $\begin{array}{l}\text { Iron } \mu \mathrm{g} / \mathrm{dL} \\
\text { Median(IQR) }\end{array}$ & $\begin{array}{l}\text { Ferritin ng/dl } \\
\text { Median(IQR) }\end{array}$ \\
\hline Infants $(n=46)$ & $64.9 \pm(16.3)$ & $150(100-212)$ & $134.2 \pm(38.3)$ & $104(73-138)$ & $53(35-123)$ \\
\hline Toddler $(n=14)$ & $60.2 \pm(18.7)$ & $218(128-352)$ & $139.4 \pm(39.6)$ & $66(35-120)$ & $45(33-75)$ \\
\hline $\begin{array}{l}\text { Preschool } \\
(n=12)\end{array}$ & $57.8 \pm(12.1)$ & $154(128-249)$ & $146.8 \pm(35.0)$ & $123(50-142)$ & 57 (24-79) \\
\hline School $(n=24)^{c}$ & $61.5 \pm(10.8)$ & $147(76-262)$ & $152.6 \pm(27.3)$ & $122(74-152)$ & $122(59-300)$ \\
\hline $\begin{array}{l}\text { Teen } \quad \text { ages } \\
(n=4)^{d}\end{array}$ & $62.5 \pm(8.8)$ & $231(116-361)$ & $169 \pm(0.0)$ & $57(25-84)$ & $107(31-309)$ \\
\hline$p$-value & $0.578(\mathrm{NS})^{\mathrm{a}}$ & $0.338(N S)^{b}$ & $0.364(\mathrm{NS})^{\mathrm{a}}$ & $0.08(N S)^{b}$ & $0.099(\mathrm{NS})^{\mathrm{b}}$ \\
\hline
\end{tabular}

\section{Discussion}

Trace elements play an important role in the pathological progression of chronic liver diseases (1) This is because these elements may have a direct hepatotoxicity (copper and iron) or may be decreased as a consequence of the impaired liver function (zinc) [1]. The results of this study showed that males with chronic liver disease were (51\%) and females were (49\%) (Table 1), while in Ibrahim et al. [1] percentage were $54 \%$ and $46 \%$ for male and female respectively, but in Rahelic et al. [5] percentage were $78 \%$ and $22 \%$ for male and female respectively.

This study showed that in case group the number of infants was $(46 \%)$, toddlers (14\%), preschool (12\%), school $(24 \%)$ and teenagers (4\%) (Table 1), in study of Kaur et al. [14] percentage of infants were $(14 \%)$, for both toddler and preschool both were (44\%) (In current study both (26\%)), school age were (32.5\%) and teenage (9.3\%). This study showed that according to Child-Pugh score classification number of patients in group A was (19\%), group B was (49\%) and group C was (23\%) (Table 1), in Rahelic et al. [5] group A the number was (35\%), (35\%) 
and (30\%) for group $B$ and $C$ respectively, in study of Maher et al. [15] group A were (26.7\%), (50\%) and (23.3\%) for group B and $C$ respectively. As for causes of chronic liver disease in case group there was no statistical significance between them (Table 2). Regarding the gender of case group there was no statistical significance, this agrees with Somi et al. [16] (Table 3).

Table 3: Comparison of the serum levels of zinc, TIBC, copper, iron and ferritin in liver disease cases group according to the gender, $n=100$.

\begin{tabular}{|l|l|l|l|}
\hline Variables & Males $(\mathbf{n}=\mathbf{5 1})$ & $\begin{array}{l}\text { Females } \\
(\mathbf{n = 4 9})\end{array}$ & -value \\
\hline $\begin{array}{l}\text { Zinc }(\mu \mathrm{g} / \mathrm{dL}) \text { Mean } \pm \\
(\mathrm{SD})\end{array}$ & $61.6 \pm(14.4)$ & $63.3 \pm(15.3)$ & $0.57(\mathrm{NS}) \mathrm{a}$ \\
\hline $\begin{array}{l}\text { TIBC }(\mu \mathrm{g} / \mathrm{dL}) \text { Median } \\
(\mathrm{IQR})\end{array}$ & $\begin{array}{l}150 \\
(112-250)\end{array}$ & $147(100-257)$ & $0.62(\mathrm{NS}) \mathrm{b}$ \\
\hline $\begin{array}{l}\text { Copper }(\mu \mathrm{g} / \mathrm{dL}) \\
\text { Mean } \pm(\mathrm{SD})\end{array}$ & $\begin{array}{l}143.8 \pm \\
-33.7\end{array}$ & $\begin{array}{l}137.4 \pm \\
-39\end{array}$ & $0.40(\mathrm{NS}) \mathrm{a}$ \\
\hline Iron $(\mu \mathrm{gg} / \mathrm{dL})$ & 121 & 95 & $0.10(\mathrm{NS}) \mathrm{b}$ \\
Median (IQR) & $(73-141)$ & $(54-132)$ & \\
\hline Ferritin (ng/dL) & 56 & 65 & $0.77(\mathrm{NS}) \mathrm{b}$ \\
\hline Median (IQR) & $(33-131)$ & $(35-98)$ & \\
\hline
\end{tabular}

Abbreviations: TIBC: Total Iron Binding Capacity, SD: Standard Deviation, IQR: Inter-Quartile Range, A: ANOVA Test, B: Kruskal-Wallis Test, C: $(N=18)$ and D: $(\mathrm{N}=1)$ Just in Copper, NS: Not Statistically Significant, *Statistically Significant at $\alpha<0.05$.

Table 4: Comparison between patients with liver diseases and normal control children regarding serum level of zinc, TIBC, copper, iron and ferritin, $n=200$.

\begin{tabular}{|l|l|l|l|}
\hline $\begin{array}{l}\text { Variables } \\
\text { Mean } \pm(\mathrm{SD})\end{array}$ & $\begin{array}{l}\text { Cases } \\
(\mathbf{n}=100)\end{array}$ & $\begin{array}{l}\text { Controls } \\
(\mathbf{n}=100)\end{array}$ & $<0.001^{*},{ }^{a}$ \\
\hline $\begin{array}{l}\text { Zinc }(\mu \mathrm{g} / \mathrm{dL}) \\
\text { Mean } \pm(\mathrm{SD}\end{array}$ & $62.5 \pm(14.8)$ & $89.6 \pm(11.3)$ & $<0.001^{*},{ }^{a}$ \\
\hline $\begin{array}{l}\text { TIBC }(\mu \mathrm{g} / \mathrm{dL}) \\
\text { Mean } \pm(\mathrm{S}\end{array}$ & $187.4 \pm(112.5)$ & $275.8 \pm(49.6)$ & $0.072(\mathrm{NS})$ \\
\hline $\begin{array}{l}\text { Copper }(\mu \mathrm{g} / \mathrm{dL}) \\
\text { Mean } \pm(\mathrm{SD})\end{array}$ & $140.7 \pm(36.3)$ & $133.6 \pm(14.1)$ & $\mathrm{a}$ \\
\hline $\begin{array}{l}\text { Iron }(\mu \mathrm{g} / \mathrm{dL}) \\
\text { Mean } \pm(\mathrm{SD})\end{array}$ & $110.7 \pm(75.7)$ & $74.8 \pm(22.1)$ & $<0.001^{*},{ }^{a}$ \\
\hline $\begin{array}{l}\text { Ferritin }(\mathrm{ng} / \mathrm{dL}) \\
\text { Median }(\mathrm{IQR})\end{array}$ & $63(34.5-127)$ & $34(26-47)$ & $<0.001^{*}, \mathrm{~b}$ \\
\hline
\end{tabular}

Abbreviations: TIBC: Total Iron Binding Capacity, SD: Standard Deviation, IQR: Inter-Quartile Rangea: Independent T-Test, B: Mann-Whitney U

Regarding serum level of trace elements, this study shows that there was significantly lower serum zinc level in the case group than the control group $(p<0.05)$ (Table 4$)$, this result is in accordance with that of Ibrahim et al. [1] , Lin et al. [2] , Suneel et al. [17] , Rahelic et al. [5] , Reddy et al. [18] and Rahopoto et al. [19] Suneel et al. mentioned that in chronic liver disease zinc levels are low because of the poor appetite, impaired function of intestine and stomach, the zinc intake and absorption decrease and also the low content of serum albumin results in less combination with zinc and because of the Diffusion characteristic of blood zinc, it is easily lost through urine and sweat [17]. Ibrahim et al. mentioned that there is a competition in the absorption of zinc between either metallothione in and copperin the intestine. Also, increased clearance of pancreatic or intestinal fluids in chronic liver disease patients, leads to the loss of zinc in the stool which is the main route of zinc excretion $[1,2]$.

Table 5: Comparison of the serum levels of zinc, TIBC, copper, iron and ferritin in liver disease cases group according to their Pugh, $n=100$.

\begin{tabular}{|c|c|c|c|c|}
\hline Variables & $\begin{array}{l}\text { Pugh A } \\
(n=19)\end{array}$ & $\begin{array}{l}\text { Pugh B } \\
(n=49)\end{array}$ & $\begin{array}{l}\text { Pugh C } \\
(n=32)\end{array}$ & p-value \\
\hline $\begin{array}{l}\text { Zinc }(\mu \mathrm{g} / \mathrm{dL}) \\
\text { Mean } \pm(\mathrm{SD})\end{array}$ & $\begin{array}{l}72.5 \\
(17.9)\end{array}$ & $\begin{array}{l}61.8 \\
(13.0)\end{array}$ & $\begin{array}{ll}57.6 & \pm \\
(12.9) & \end{array}$ & $0.002^{*}, \mathrm{a}$ \\
\hline $\begin{array}{l}\text { TIBC }(\mu \mathrm{g} / \mathrm{dL}) \\
\text { Median IQR) }\end{array}$ & $\begin{array}{l}250 \\
(147-352)\end{array}$ & $\begin{array}{l}165 \\
(110-256)\end{array}$ & $\begin{array}{l}124 \\
(76-177)\end{array}$ & $<0.001^{*}$ \\
\hline $\begin{array}{l}\text { Copper } \\
(\mu g / d L) \\
\text { Median (IQR) }\end{array}$ & $\begin{array}{l}117 \\
(103-164)\end{array}$ & $\begin{array}{l}154 \\
(115-169)\end{array}$ & $\begin{array}{l}159 \\
(101-172)\end{array}$ & $\begin{array}{l}0.27^{\mathrm{b}} \\
(\mathrm{NS})\end{array}$ \\
\hline $\begin{array}{l}\text { Iron }(\mu \mathrm{g} / \mathrm{dL}) \\
\text { Median (IQR) }\end{array}$ & $\begin{array}{l}73 \\
(51-132)\end{array}$ & $\begin{array}{l}110 \\
(79-126)\end{array}$ & $\begin{array}{l}116 \\
(54-152)\end{array}$ & $\begin{array}{l}0.18^{b} \\
\text { (NS) }\end{array}$ \\
\hline $\begin{array}{l}\text { Ferritin } \\
(\mathrm{ng} / \mathrm{dL}) \\
\text { Median (IQR) }\end{array}$ & $\begin{array}{l}63 \\
(33-75)\end{array}$ & $\begin{array}{l}72 \\
(41-123)\end{array}$ & $\begin{array}{l}46.5 \\
(31-148)\end{array}$ & $\begin{array}{l}0.54^{\mathrm{b}} \\
\text { (NS) }\end{array}$ \\
\hline
\end{tabular}

Abbreviations: TIBC: Total Iron Binding Capacity, SD: Standard Deviation, IQR: Inter-Quartile Range, A: ANOVA Test, B: Kruskal Wallis Test, NS: Not Statistically Significant, *Statistically Significant at $\alpha<0.05$.

This study shows an increase in the copper level in case group as compared with controls but it was statistically not significant (Table 4), Ibrahim et al. [1] and Suneel et al. [17] both found an increase in copper level in chronic liver disease patients as compared with control, it is known that chronic liver disease may lead to cholestasis as a result of either a functional defect in bile formation at the level of hepatocytes, or from impairment in bile secretion and flow at the bile ducts level causing impaired biliary excretion of copper and excess copper absorption, also in chronic liver disease decrease synthesis of ceruloplasmin that leads to high copper level in liver disorders [1,17].

The mean serum iron level in this study was significantly higher in case group than that of control group $(p<0.05)$ (Table 4). this is in agreement with the work of Ibrahim et al. [1] who found an increase in serum iron level in chronic liver disease patients as compared with control group, also the study in agreement with Lin et al. [2] who found an increased iron level in chronic hepatitis B infection as compared with control group, in contrast to other studies Buyukasik et al. [20] and Mahmood et al. [21] who both found that there was no significant difference in serum iron level in chronic liver disease patients and control groups.

This study shows that there was significantly lower serum total iron binding capacity level in case group than the control 
group ( $p<0.05)$ (Table 4). This agrees with the study of Ibrahim et al. [1] and Buyukasik et al. [20], who both found a decrease level of total iron binding capacity in patient as compared with control group as mentioned previously that total iron binding capacity reflects transferrin activity and the later produced in liver and its production decrease liver damage [20].

The present study shows that serum ferritin level was significantly higher in case group than the control group $(p<0.05)$ (Table 4). This is in agreement with Ibrahim et al. [1] and Buyukasik et al. [20], who both found an increase in serum ferritin in liver disease patients more than control, this increase due to increase iron level $[1,12]$. In this study regarding cause of chronic liver the most common causes were biliary atresia (25\%) and undiagnosed chronic liver disease (25\%) while autoimmune hepatitis was the least cause (9\%) (Figure 1).

There was a decrease in serum zinc level in Pugh-score group $C$ in comparison with group $A$ and $B$ with statistical significance $(p<0.05)$ (Table 5$)$, these results were in agreement with Somi et al. [16] who found a decrease in serum zinc level in Pugh-score group $B$ than group $A$ due to decrease serum albumin level, also in agreement with Maher et al. [15] who found a decrease in serum zinc level as Pughscore increase in severity as many factors can explain this low zinc level, decrease intake and anorexia in advanced liver disease, decreased absorption due to intestinal congestion caused by portal hypertension, decrease bioavailability of zinc bound to albumin and to $\alpha$ macroglobulin, thus in advanced chronic liver disease, where protein synthesis by the liver is more severely impaired, zinc deficiency is augmented [15]. The present study showed disagreement with Rahelic et al. [5] who found no statistical significance in serum zinc level according to Child-Pugh score.

As for serum copper this study showed increased serum copper in Pugh-score group $C$ more than group $A$ and $B$ but it was not statistically significant (Table 5), this is in agreement with Rahelic et al. [5] and Somi et al. [16] who related that to the release of copper from damaged hepatocytes and in severe liver disease there is more hepatocyte injury especially in cirrhosis and late stage liver disease.

This study showed that serum iron level in Pugh-score $C$ was more than group $A$ and $B$ but with no statistical significance (Table 5), this result disagreed with Somi et al. [16] who found a decrease in iron level in Pugh-score group $C$ less than group $A$ and $B$ that is mostly related to the nutritional deficiency, but it agreed with Buyukasik et al. [20] who found an increase serum iron as Pugh-score increase in severity. This study showed there is a difference in serum total iron binding capacity as the level decrease as Pugh-score increase in severity (Pugh-score group $C$ lower than group $A$ and $B$ and the difference was statistically significant $(p<0.05)$ (Table 5$)$, this is in agreement with Buyukasik et al. [20] who related that to the decrease transferrin production by damaged hepatocytes (total iron binding capacity reflect transferrin activity [20].

In this study serum ferritin level shows an increment as Pugh-score increase in severity (Pugh-score group B higher than group A) but with no statistical significance (Table 5), this is in agreement with Buyukasik et al. [20], damaged hepatocytes lead to decreased hepcidin level thus increasing iron absorption, more liver damage less hepcidin more iron absorption.

\section{Conclusion}

Serum zinc, copper and iron could be included in the assessment of children with chronic liver disease. Zinc supplementation may be encouraged children with chronic liver disease even if it is normal as it is an antioxidant and it is negatively correlated with liver damage parameter. Caution regarding iron and copper intake either dietary or medicinal. The level of copper, zinc and iron may serve children with as biomarkers for monitoring the increase severity of liver damage.

\section{References}

1. Ibrahim NL (2013) Study of serum copper and iron in children with chronic liver disease. Anatomy and physiology 4: 1-15.

2. Lin C, Huang J, Tsai L, Huang Y (2006) Selenium, iron, copper and zinc levels and copper to zinc ratio in serum of patients at different stages of viral hepatic disease. Biol Trace Elem Res 109: 16.

3. Kolachi NF, Kazi TG, Afridi HI (2012) Investigation of trace and toxic elements in biological samples (blood, serum and scalp hair) of liver cirrhotic patients before and after mineral supplements. Clin Natr 13: 967-973.

4. Cobine PA, Pierrel F, Winge DR (2006) Copper trafficking to mitochndrion and assembly of copper metalloenzymes. Biochem Biophys Acta 1763: 759-772.

5. Rahelic D, Kujundzic M, Romic Z, Brkick K, Petrovecki M (2006) Serum concentration of zinc, copper, manganese and magnesium in patients with liver cirrhosis. Coll Antropol 3: 523.

6. Tao TY, Gitlin JD (2003) Hepatic copper metabolism: Insight from genetic disease. Hepatology 37: 1241-1245.

7. Mohammad MK, Zhou Z, Cave M, Brave A, Mc Clain CJ (2000) Zinc and liver disease. Nutr Clin Pract 27: 8-16.

8. Deugnier $\mathrm{Y}$, Brissot $\mathrm{P}$, Lorealo $\mathrm{P}$ (2008) Iron and the liver update. Journal Hepatol 48: 113-123.

9. Buyukasik NS, Nadir I, Akin FE, Cakal B, Kav T, et al. (2011) Serum iron parameters in cirrhosis and chronic hepatitis: detailed description. Turk J Gastroenterol 22: 606-611.

10. Arredono M, Nunez MT (2005) Iron and copper metabolism. Mol Aspects Med 26: 313-327.

11. Shnider BL, Suchy FJ (2011) Autoimmune hepatitis In: Nelson text book of pediatrics. (19th edn) Elsevier, Philadelphia. pp. 1408-1410.

12. Moore KP, Wong F, Gines P, Bernardi M, Ochs A, et al. (2003) The management of ascites in cirrhosis: Report on the consensus conference of the International Ascites Club. Hepatology 38: 258-266.

13. SuchyFJ (2011) Fulminant hepatic failure, in Nelson text book of pediatrics. (19th edn). Elsevier, Philadelphia. pp. 1412-1415. 
14. Kaur S, Kumar P, Kumar V, Sarin SK, Kumar A (2013) Etiology and prognostic factors of acute liver failure in children. Indian Pediatr 50: 677-679.

15. Maher M, Yosef TM, Sabry Al, Saleh SA, Alkady H (2013) Hyponatremia and zinc deficiency as a risk factor for hepatic encephalopathy in cirrhotic patients. Life Sci 10: 1493-1500 .

16. Somi MH, Rahimi AO, Moshrefi B, Rezaeifar P, Maghami JG (2007) Nutritional status and blood trace elements in cirrhotic patients. Hepatitis Monthly 7: 27-32.

17. Suneel B, Balakrishna D, Sridhar M, Aparna RR, Sowjanya B (2012) Zinc, copper, C-reactive protein and lipid peroxidation in chronic liver diseases. Biochemistry 13: 313-319.
18. Reddy NRP, Kishore A, Franklin A, Reddy EP (2012) Evaluation of trace elements in hepatitis B. J Pharm Biomed Sci 21: 1-3.

19. Rahopoto Q, Shaikh S, Shaikh M, Mastoi A, Aalmani S (2010) Serum copper and zinc concentration in patients with chronic hepatitis C. Medical Channel 16: 27-29 .

20. Buyukasik NS, Nadir I, Akin FE, Cakal B, Kav T, et al. (2011) Serum iron parameters in cirrhosis and chronic hepatitis: detailed description. Turk J Gastroenterol 22: 606-611.

21. Mahmood Z, Riaz A, Riaz M (2013) Investigation of selective biochemical markers from chronic hepatitis $C$ patients in relation to environmental pollutants. World Appl Sci J 24 : 1084-1090. 